\title{
Beberapa Catatan tentang Peradilan Tata Usaha Negara di Indonesia
}

\author{
Ridwan
}

\begin{abstract}
Institution as the human product is not steril from the various factors like politics, economy, culture and so forth, including the Acts number. 5, 1986 about juristiction of State Procedure, therefore the Acts innovation is surely needed towards the better condition, just and relevance to the society development. This article is aimed as a thinking contribution in the frame of innovation for the Acts number. 5, 1986 by restricting for the three points including the problem existing sorrounding it namely material and the reason of accusation, the meaning of board or official of state procedure as the accused and realization of decision.
\end{abstract}

\section{Pendahuluan}

Segera setelah UU No. 5 Tahun 1986 tentang Peradilan Tata Usaha Negara' dinyatakan berlaku pada tahun 1991, setelah masa persiapan selama lima tahun, berbagai perkara mulai diajukan ke PTUN terutama gugatan terhadap instansi yang banyak melakukan fungsi pelayanan kepada masyarakat seperti Badan Pertanahan Nasional (BPN), Perusahaan Listrik Negara (PLN), dan Pemerintah Daerah. Banyaknya gugatan yang masuk ke PTUN itu mengindikasikan dua hal; Pertama, warga masyarakàt semakin berani dalam membela

haknya; Kedua, menunjukan bahwa pelaksanaan administrasi di negeri ini masih rentan. Agaknya kehadiran PTUN ini gaungnya menerpa ke dua arah; kepada masyarakat, yang melahirkan kesempatan untuk membela hak-haknya akibat perbuatan pemerintah yang menyimpang, dan kepada pemerintah atau administrasi negara, yang - setidaktidaknya- dapat mendorong pemerintah untuk bertindak cermat, hati-hati, dan lebih menghormati hak-hak rakyat.

'Selanjutnya UU No. 5 Tahun 1986 Tentang Peradilan Tata Usaha Negara dalam tulisan ini disebut UU PTUN. 
Kehadiran PTUN disambut gembira oleh masyarakat, tetapi tidak demikian halnya dengan sebagian pejabat pemerintah. Sebagian pejabat pemerintah berusaha mencari celah-celah yang memungkinkan untuk menghindarinya. Ada Surat Keputusan Gubernur yang digugat kemudian Surat. Keputusan itu diganti dengan Peraturan Daerah (Perda), yang berarti berada di luar kewenangan PTUN, ${ }^{2}$ banyak pejabat yang kalah berperkara, namun tidak mau mematuhi putusan pengadilan yang sudah.mempunyai kekuatan hukum tetap dan tidak terdapat upaya yang dapat memaksa pejabat untuk mematuhi putusan pengadilan itu. Di samping itu, banyak pula gugatan terhadap tindakan pemerintah, namun ditolak karena dianggap tidak termasuk kompetensi PTUN. Berkenaan dengan hal-hal tersebut tampak bahwa UU PTUN masih mengandung beberapa kelemahan atau kekurangan yang perlu dibenahi.

Ketika pada 20 Januari 2001 di Jakarta diselenggarakan peringatan sepuluh tahun berlakunya UU PTUN, Paulus E. Lotulung menganggap perlu melakukan revisi terhadap undang-undang tersebut, di antaranya ia mengemukakan agar objek gugatan dilakukan perubahan, tidak hanya mengenai tindakantindakan hukum tata usaha negara saja tetapi lebih luas lagi, yaitu tindakan-tindakan hukum publik. la juga mengusulkan agar pencari keadilan terhadap sengketa tata usaha negara tidak hanya rakyat saja, tetapi juga termasuk badan atau pejabat tata usaha negara. Di samping itu, perubahan diperlukan sehubungan dengan adanya perubahan UU No. 14 Tahun 197.0 menjadi UU No. 35 Tahun 1999 tentang Ketentuan Pokok Kekuasaan Kehakiman dan sehubungan dengan lahirnya UU No. 22 Tahun 1999 tentang Pemerintahan Daerah. ${ }^{3}$ Jauh sebelumnya, Paulus E. Lotulung telah mengemukakan beberapa problematika yang terdapat dalam undangundang tersebut baik mengenai hukum materilnya maupun hukum acaranya. Problematika yang berkenaan dengan hukum materil di antaranya tentang pengertian "pejabat tata usaha negara", . Paulus mempertanyakan apakah termasuk badan swasta yang, menjalankan pelayanan umum dalam bidang pemerintahan? Apakah termasuk pula Ketua Pengadilan Negeri atau Ketua Mahkamah Agung?4

Terlepas dari berbagai persoalan yang dikemukakan oleh pakar hukum administrasi tersebut, satu hal yang perlu dikemukakan adalah bahwa undang-undang sebagai karya manusia bukanlah sesuatu yang steril dari berbagai faktor yang ada pada saat pembentukannya seperti faktor politik, situasi ekonomi, sosial, dan budaya. Oleh karena itu, pembaharuan UU PTUN menuju peradilan yang lebih baik dan sesuai dengan kondisi zaman bukan saja diperlukan, tetapi justru menjadi keharusan. Tulisan sederhana ini tidak bermaksud untuk menawarkan

${ }^{2}$ Forum Keadilan No. 28. Maret 1991. HIm. 25.

${ }^{3}$ Lihat Varia Peradilan No. 186 Tahun 2001. HIm. 132-134.

${ }^{4}$ Paulus E. Lotulung. "Problematika PTUN." Makalah pada Penataran Hukum Administrasi Negara. Diselenggarakan di Fakultas Hukum Universitas Airlangga. Surabaya, 13 Januari 1995. HIm. 7 
pembaharuan total terhadap problematika yang terdapat dalam UU PTUN, namun hanya akan membatasi pada beberapa hal'saja, yaitu mengenai objek dan alasan gugatan, pengertian badan atau pejabat tata usaha negara selaku pihak tergugat, dan pelaksanaan putusan.

\section{Objek dan Alasan Gugatan Tata Usaha Negara}

Berdasarkan UU PTUN yang menjadi objek gugatan atau pangkal sengketa tata usaha negara adalah KTUN yang dikeluarkan oleh badan atau pejabat tata usaha negara yang mengandung unsur bertentangan dengan peraturan perundang-undangan yang berlaku, penyalahgunaan wewenang, dan tindakan sewenang-wenang. Di atas telah disebutkan, Paulus E. Lotulung selaku Ketua Tim Revisi UU PTUN mengusulkan agar objek gugatan diperluas lagi meliputi tindakantindakan hukum publik. Sekilas usulan Paulus ini dapat diterima dengan baik karena berarti akan terbuka peluang yang lebih luas bagi masyarakat untuk menggugat berbagai tindakan hukum publik, namun apabila usulan tersebut diterima, maka akan terjadi pencampuradukan proses peradilan atau melampaui kompetensi absolut PTUN.

Secara teoretis tindakan hukum adalah "de handelingen die naar hun aard zijn gericht op een bepaald rechtsgevolg"s (tindakantindakan yang berdasarkan sifatnya dimaksudkan untuk menimbulkan akibat hukum tertentu) atau "een rechtshandeling is gericht op het scheppen van rechten of plichten"6 (tindakan hukum adalah tindakan yang dimaksudkan untuk menciptakan hak dan kewajiban). Berdasarkan pengertian ini tindakan hukum publik berarti tindakantindakan hukum yang didasarkan pada hukum publik dan menimbulkan akibat-akibat yang bersifat publik (publiekrechtelijk). Tindakan hukum yang didasarkan pada hukum publik itu dapat dilakukan baik oleh organ administrasi negara maupun organ kenegaraan. Atas dasar pengertian ini, maka dalam kaitannya dengan peradilan tata usaha negara, pengertian tindakan hukum publik yang diusulkan oleh Paulus tersebut harus dibatasi pada tindakan-tindakan hukum publik yang dilakukan oleh pemerintah dalam bidang administrasi. Dalam bidang administrasi, "een administratieve rechtshandeling is dan een wilsverklaring in een bijzonder geval uitgaande van een administratief orgaan, gericht op het in het leven roepen van een rechtsgevolg op het gebeid van administratief recht" (tindakan hukum administrasi adalah suatu pernyataan kehendak yang muncul dari organ administrasi dälam keadaan khusus, dimaksudkan untuk menimbulkan akibat hukum dalam bidang hukum administrasi). Tindakan hukum publik dalam bidang administrasi ini terbagi ke dalam tindakan hukum publik beberapa pihak dan tindakan hukum publik sepihak. Lebih lanjut, tindakan hukum publik sepihak ini terbagi lagi

${ }^{5}$ R.J.H.M. Huisman. Tt. Algemeen Bestuursrecht, een Inleiding. Amsterdam: Kobra. HIm. 13

6J.B.J.M. ten Berge. 1996. Besturen door de Overheid. Deventer:W.E.J. Tjeenk Willink. HIm. 137

${ }^{7}$ H.J. Romeijn. 1934. Administratiefrecht Hand-en Leerboek. Den Hāag: Moorman's Periodieke Pers N.V.HIm. 89 
menjadi tindakkan hukum publik yang bersifat pengaturan (regeling) dan tindakan hukum publik yang bersifat penetapan (beschikking).
Secara garis besar, pembagian tindakan. hukum yang dapat dilakukan oleh administrasi negara dapat dilihat pada bagan berikut ini:

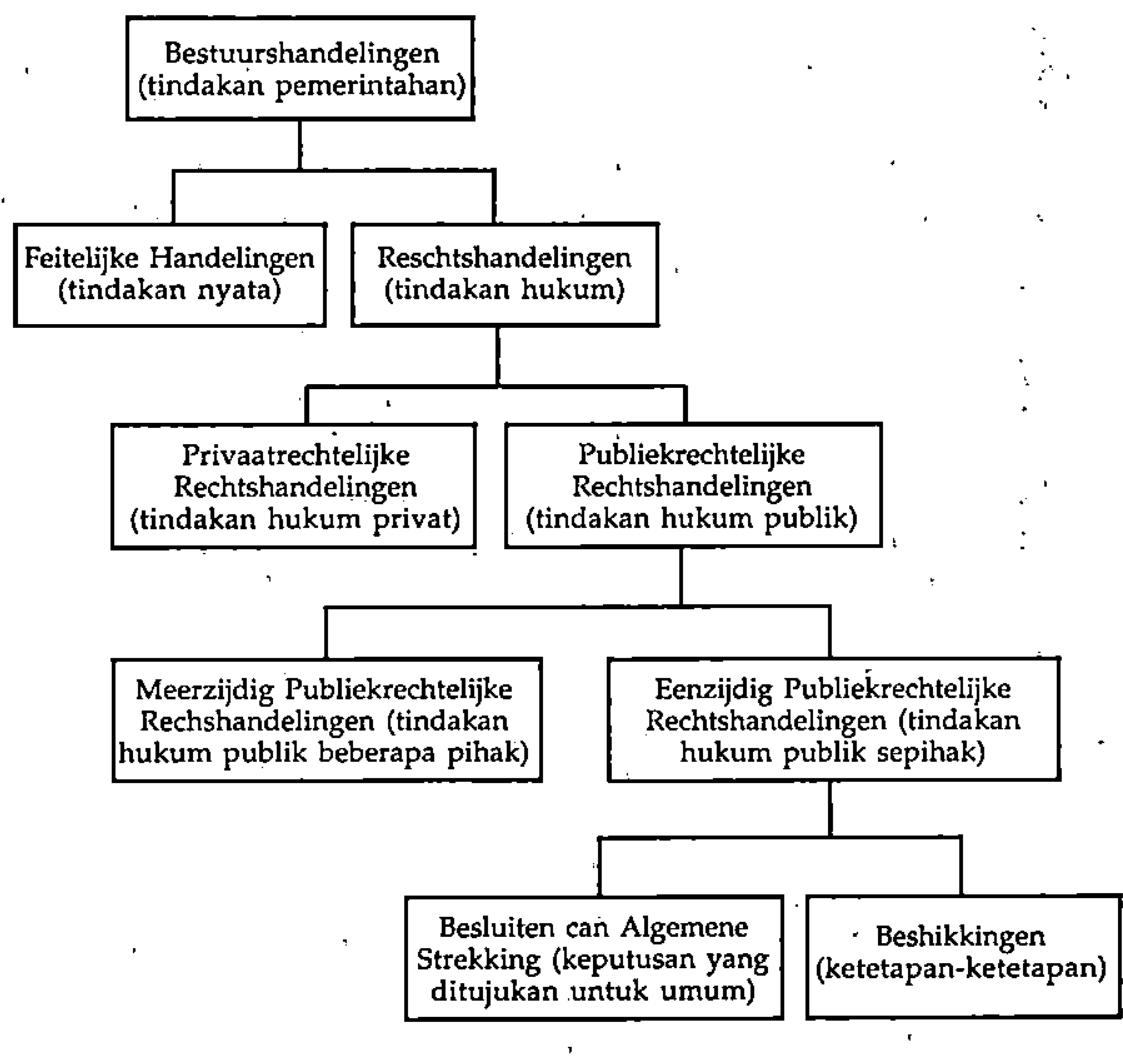

(Sumber: Algemene Bepalingen van Administratief Recht, hlm. 5)

Berdasarkan bagan ini tampak bahwa dalam tindakan hukum publik yang dilakukan oleh administrasi negara itu termasuk pula tindakan hukum beberapa pihak dengan menggunakan instrumen hukum peraturan bersama (gemeenschappelijk regeling), tindakan hukum sepihak yang bersifat pengaturan dengan instrumen hukum keputusan yang bersifat umum (bes/uit van algemene strekking), dan tindakan hukum penetapan dengan menggunakan instrumen hukum ketetapan-ketetapan (beschikkingen). 
Penggunaan instrumen hukum peraturan bersama adalah untuk mengatur tindakan hukum antara dua subjek hukum atau lebih, yang biasanya digunakan untuk mengatur kerja sama antar organ pemerintahan. Di negeri Belanda, instrumen hukum ini dituangkan dalam bentuk undang-undang untuk mengatur kerja sama antar Daerah yaitu wet gemeenschappelijke regeling. ${ }^{8}$ Keputusan yang bersifat umum digunakan oleh organ pemerintahan untuk mengatur hal yang bersifat umum, karena itu keputusan ini norma hukum abstrak-umum atau umum-abstrak, dan ia termasuk sebagai peraturan perundangundangan. ${ }^{9}$. Dengan kata lain, peraturan bersama dan keputusan yang bersifat umum merupakan peraturan perundang-undangan. Sebagai suatu peraturan perundangundangan, peraturan bersama dan keputusan yang bersifat umum tidak dapat dijadikan objek sengketa dalam proses peradilan tata usaha negara. Pengujian terhadap peraturan perundang-undangan adalah kewenangan dari Mahkamah Agung, sebagaimana ditentukan Pasal 5 ayat (2) Tap MPR No. IIII MPR/2000 tentang Sumber Hukum dan Tata Urutan Peraturan Perundang-undangan, yang menegaskan bahwa "Mahkamah Agung berwenang menguji peraturan perundangundangan di bawah undang-undang".
Ketentuan bahwa Mahkamah Agung berwenang menguji secara materiil peraturan perundang-undangan di bawah undangundang terdapat pula dalam Pasal 26 UU No. 14 Tahun 1970 yang telah dirubah dengan UU No. 35 Tahun 1999 tentang Ketentuanketentuan Pokok Kekuasaan Kehakiman; "Mahkamah Agung berwenang untuk menyatakan tidak sah semua peraturan perundang-undangan dari tingkat yang lebih rendah dari undang-undang atas alasan bertentangan dengan peraturan perundangundangan yang lebih tinggi". Ketentuan yang sama juga terdapat dalam Pasal 31 ayat (1) UU No. 14 Tahun 1985 tentang Mahkamah Agung; "Mahkamah Agung mempunya, wewenang menguji secara materiil hanya terhadap peraturan perundang-undangan di bawah undang-undang". Dengan demikian, menjadikan tindakan hukum publik sebagai objek gugatan, dengan tanpa pemilahan secara tegas jenis-jenis tindakan hukum publik yang dapat dilakukan oleh pemerintah akan menyebabkan pencampuradukan kompetensiperadilan dan melampau batas kompetensi absolut PTUN. Telah jelas bahwa ada tindakan hukum publik pemerintah yang merupakan pengaturan (regeling) dan menjadi kewenangan Mahkamah Agung untuk mengujinya.

'W. Derksen en A.F.A. Korsten (redactie). 1989. Lokaal Bestuur in Nederland. Alphen aan den Rijn' Samsom H.D. Tjeenk Willink. HIm. 234, lihat pula P. de Haan, et.al.. 1986. Bestuursrecht in de Sociale Rechtstaat. Deel 2:Deventer: Kluwer. HIm. 95

'Berdasarkan Penjelasan Pasal 1 angka 2 UU No. 5 Tahun 1986, peraturan perundang-undangari adalah semua peraturan yang bersifat mengikat secara umum yang dikeluarkan oleh Badan Perwakilan Rakyar bersama Pemerintah baik di tingkat pusat maupun di tingkat daerah, serta semua Keputusan Badan atau Pejaba: Tata Usaha Negara baik di tingkat pusat maupun di tingkat daerah yang juga mengikat umum. 
Berdasarkan bagan tersebut di atas, yang dapat menjadi objek gugatan hanyalah tindakan hukum publik pemerintah yang berupa beschikking. (ketetapan), ${ }^{10}$ sebagai inștrumen hukum publik yang digunakan oleh pemerintah yang memiliki sifat sepihak (eenjizdige) dan ditujukan untuk hal yang bersifat individual. Instrumen hukum publik pemerintah yang tidak memiliki sifat sepihak dan individual, dengan sendirinya tidak dapat disebut sebagai ketetapan dan tidak dapat menjadi objek sengketa tata usaha negara. Hal ini berarti bahwa rumusan tentang perkecualian KTUN yang tercantum dalam Pasal 2 UU PTUN menjadi tidak diperlukan, karena KTUN yang merupakan perbuatan perdata, merupakan ,pengaturan yang bersifat umum, dan lain-lain ${ }^{11}$ dengan sendirinya tidak dapat disebut ketetapan.
Berkenaan dengan objek gugatan, agaknya yang diperlukan bukan memperluas cakupań objek gugatan; tetapi merevisi dan menambah alat uji atau dasar penilaian (toetsingsgrond) terhadap gugatan, tidak hanya sekadar apa yang tercantum dalam Pasal 53 ayat (2).$^{12}$ Revisi perlu dilakukan terhadap Pasal 53 ayat (2) sub $c$ yaitu unsur sewenangwenang diubah menjadi "nyata-nyata tidak beralasan atau bertentangan dengan nalar sehat" (kennelijk onredelijk). Sewenangwenang (willekeur) adalah konsep abstrak yang sukar diukur atau dinilai, sementara kennelijk onredelijk dianggap 'lebih operasional sehingga menjadi terukur. ${ }^{13}$ Menambah alat uji perlu pula dilàkukan dengan mencantumkan secara tegàs asasasas umum pemerintähan yang layak dalam Pasal 53 ayat (2), sehingga KTUN yang digugat

${ }^{10} \mathrm{Dikalangan}$ para sarjana Indonesia istilah beschikking ada yang menerjemahkan dengan keputusan dan ada pula yang menerjemahkannya dengan ketetapan. Penulis cenderung menggunakan istilah ketetapan sebagai terjemahan dari beschikking, hal ini untuk membedakan dengan istilah' besluit yang lebih tepat diterjemahkan dengan keputusan, sebagai suatu instrumen hukum yang bersifat mengatur.

"Secara lengkap bunyi Pasal 2 adalah sebagai berikut; Tidak termasuk dalam pengertian KTUN menurut undang-undang ini: (a) KTUN yang merupakan perbuatan hukum perdata; (b) KTUN yang merupakan pengaturan yang bersifat umum; (c) KTUN yang masih memerlukan persetujuan; (d) KTUN yang dikeluarkan berdasarkan KUHP dan KUHAP atau peraturan perundang-undangan lain yang bersifat hukum pidana; (e) KTUN yang dikeluarkan atas dasar hasil pemeriksaan badan peradilan 'berdasarkan ketentuan peraturan perundang-undangan yang berlaku; (f) KTUN mengenai tata usaha ABRl; dan (g) Keputusan Panitia Pemilihan, baik di pusat maupun di daerah, mengenai hasil pemilihan umum.

${ }^{12} \mathrm{Pasal} 53$ ayat (2) berbunyi; Alasan-alasan yang dapat digunakan dalam gugatan sebagaimana dimaksud dalam ayat (1) adalah:

a. KTUN yang digugat itu bèrtentangan dengan peraturan perundang-undangani yang berlaku;

b. Badan atau Pejabat TUN pada waktu mengeluarkan keputusan sebagaimana dimaksud dalam ayat (1) telah menggunakan wéwenangnya untuk tujuan lain dari maksud diberikannyà wewenang tersebut;

c. Badan atau Pejabat TUN pada waktu mengeluarkan atau tidak mengeluarkan keputusan sebagaimana dimaksud dalam ayat (1) setelah mempertimbangkan semua kepentingan yang tersangkut dengan keputusan itu seharusnya tidak sampai pada pengambilan keputusan tersebut.

${ }^{13}$ Philipus M. Hadjon, et.al. 1993. Pengantar Hukum Administrasi Indonesia. Yogyakarta: Gadjah Mada University Press. HIm. 325. 
tidak hanya karena bertentangan dengan peraturan perundang-undangan, mengandung unsur penyalahgunaan wewenang, dan ada unsur sewenangwenang, tetapi fuga bertentangan dengan asas-asas umum pemerintahan yang layak. Dengan demikian, asas-asas umum pemerintahan yañg layak dijadikan sebagai alat uji sub d dari Pasal 53 ayat (2). ${ }^{14}$

Meskipun ada penambahan alat.uji terhadap KTUN yang digugat, namun prinsip bahwa hakim boleh menguji KTUN itu hanya dari aspek hukum (rechtmatigheid) harus tetap dipertahankan. Hakim PTUN tidak boleh menguji aspek kebijaksaan pemerintah (geen ordeel over de doelmatigheid), hakim tidak diperkenankan memasuki wilayah pemerintah, "'de rechter niet op de stoel van de administratie gaan zitten ${ }^{i}$. (hakim tidak boleh duduk di atas kursi pemerintahan). Artinya meskipun hakim tidak setuju terhadap kebijaksanaan pemerintah, hakim hanya boleh menguji KTUN dari aspek hukumnya saja (ordeel over de rechitmatigheid). Ini merupakan konsekuensi dari ajaran pemisahan atau pembagian kekuasaan negara (machtenscheiding of machtensverdeling), yang menempatkan organ-organ pemerintahan dan kenegaraan berjalan sesuai dengan kewenangannya masing-masing.

\section{Badan atau Pejabat Tata Usaha Negara}

Dalam proses peradilan tata usaha negara, Badan atau Pejabat Tata Usaha Negara selalu' ditempatkan sebagai pihak tergugat, sebagaimana ditentukan dalam Pasal 1 angka (6); "Tergugat adalah Badan atau Pejabat: Tata Usaha Negara yang mengeluarkan keputusan berdasarkan wewenang yang ada padanya atau yang dilimpahkan kepadanya, yang digugat oleh orang atau badan hukum perdata". Lalu siapa yang dimaksud dengan Badan atau Pejabat Tata Usaha Negara? Menurut ketentuan Pasal 1 angka (2) UU PTUN; "Badan atau Pejabat Tata Usaha Negara adalah Badan atau Pejabat yang melaksanakan urusan pemerintahan berdasarkan peraturan perundang-undangan yang berlaku". Di dalam penjelasan disebutkan bahwa yang dimaksud dengan urusan pemerintahan ialah kegiatan yang bersifat eksekutif. Rumusan ini masih ambigu dan tidak jelas (vague), yang di dalam praktek dapat menimbulkan penafsiran yang beragam. Apakah kegiatan yang bersifat eksekutif sama artinya dengan kegiatan yang bersifat pemerintahan dalam pengertian modern/ mutakhir? Kegiatan yang bersifat pemerintahan itu tidak hanya kegiatan dalam rangka pelaksanaan undang-undang. Menurut Philipus $M$. Hadjon, di negara

${ }^{14}$ Sementara belum ada ketentuan baku tentang asas-asas umum pemerintahan yang layak, kepada hakim diberikan kewenangan untuk mencari dan menggali asas-asas umum pemerintahan yang layak dalam khazanah kepustakaan hukum dan nilai-nilai yang berkembang di tengah masyarakat. Dengan cara demikian, seiring dengan perkembangan peradilan akan lahir berbagai yurisprudensi yang berkenaan dengan asasasas tersebut. Keweñangan hakim untuk mencari dan menggali asas-asas itu memiliki sandaran hukum yang jelas yaitu Pasal 14 dan 27 ayat (1) UU No. 14 Tahun 1970 yang telah diperbaharui dengan UU No. 35 Tahun 1999 tentang Ketentuan-ketentuan Pokok Kekuasaan Kehakiman.

${ }^{15}$ A.D. Belinfante. 1985. Kort Begrip van het Administratief Recht. Alphen aan den Rijn: Samsom Uitgeverij. HIm. 109 
manapun tidak pernah terjadi bahwa kekuasaan pemerintahan hanyalah murni melaksanakan undang-undang. ${ }^{16}$ Kegiatan pemerintahan lebih luas daripada kegiatan yang bersifat eksekutif. Kegiatan pemerintahan adalah "alle activiteiten van de overheid die niet als wetgeving en rechtspraak zijn aan te merken $^{n 17}$ (semua aktivitas pemerintah selain kegiatan pembuatan undang-undang dan peradilan). Seiring dengan dianutnya konsep negara hukum modern (welfare state, verzorgingsstaat) yang memberikan kewajiban kepada pemerintah untuk terlibat aktif dalam kegiatan ekonomi dan sosial dalam upaya mewujudkan kesejahteraan umum, kegiatan pemerintah itu demikian luas. Oleh karena itu dalam praktek kegiatan pemerintahan tidak hanya dijalankan oleh organ pemerintahan yang sudah dikenal. secara konvensional seperti Presiden beserta perangkatnya, Kepala Daerah beserta perangkatnya, Lurah beserta perangkatnya, dan cabang-cabang: organ pemerintahan lainnya, tetapi juga dijalankan oleh badan-badan hukum swasta yang mendapatkan kewenangan tertentu untuk menjalankan sebagian urusan pemerintahan. Indroharto berpendapat bahwa ukuran untuk dikatagorikan sebagai Badan atau Pejabat Tata Usaha Negara adalah fungsi yang dijalankannya. Apabila yang diperbuat itu berdasarkan peraturan perundang-undangan yang berlaku merupakan suatu pelaksanaan dari urusan pemerintahan, maka apa saja dan siapa saja yang melaksanakan fungsi demikian itu pada saat itu dianggap șebagai Badan atau Pejabat Tata Usaha Negara. ${ }^{18} \mathrm{Hal}$ ini membawa konsekuensi bahwa yang dapat menjadi tergugat dalam sengketa tata usaha negara tidak hanya organ-organ pemerintahan, namun termasuk juga badanbadan hukum lain yang secara organisatoris tidak termasuk ke dalam organisasi pemerintahan. Berbagai yurisprudensi PTUN telah memperlihatkan bahwa badan-badan hukum swasta dapat menjadi tergugat dalam sengketa tata usaha negara dengan alasan badan tersebut menjalankan sebagian urusan pemerintahan. Agaknya perkembangan peradilan tata usaha telah memperluas pihak tergugat, tidak hanya Badan atau Pejabat Tata Usaha Negara tetapi juga badan-badan swasta. Dengan demikian, pengertian pihak tergugat sebagaimana dirumuskan dalam Pasal 1 angka (6) perlu ditinjau ulang.

Meskipun berbagai yurisprudensi telah menempatkan badan-badan perdata yang diberi wewenang untuk menjalankan sebagian urusan pemerintahan selaku pihak tergugat, namun sesungguhnya hal ini menyimpan persoalan yang harus dipecahkan, misalnya ada badan swasta mengeluarkan ketetapan yang menimbulkan

${ }^{16}$ Philipus M. Hadjon. "Pemierintahan Menurut Hukum (Wet-en Rechtmatig Bestuur)." Makalah tidak dipublikasikan. HIm. 1

${ }^{17}$ C.J.N. Versteden. 1984. Inleiding Algemeen Bestuursrecht. Alphen aan den Rijn: Samsom H.D. Tjeenk Willink. HIm. 13

${ }^{18} \mid$ ndroharto. 1994. Usaha Memahami Undang-undang tentang Peradilan Tata Usaha Negara. Buku I. Jakarta: Pustaka Sinar Harapan. HIm. 165 
kerugian bagi seseorang lalu digugat di PTUN, tetapi tiba-tiba badan swasta itu dinyatakan bubar atau dibubarkan. Dalam hal demikian, bagaimana dan siapa yang harus bertanggungjawab terhadap kerugian tersebut? Persoalan lain yang tak kalah penting untuk ségera dipecahkan adalah penentuan kriteria mengenai badan swasta yang menjalankän urusan pemerintahan. Dengan kata lain, apa ukurannya badan swasta itu dikatagorikan atau "dipersamakan" dengan Badan atau Pejabat TUN, sehingga ia ditempatkan sebagai tergugat? Apakah sekadar anggapan bahwa badan itu melaksanakan sebagian fungsi pemerintahan? Lebih lanjut, apa yang dimaksud dengan fungsi pemerintahan? Bukankah pengertian fungsi pemerintahan inipun tidak jelas, apalagi dengan perkembangan sekarang terutama dengan konsep swastanisasi? Sehubungan dengan rencana revisi terhadap UU PTUN, persoalan-persoalan tersebut perlu diperhatikan.

\section{Pelaksanaan Putusan PTUN}

Putusan hakim adalah suatu pernyataan yang oleh hakim, sebagai pejabat negara yang diberi wewenang untuk itu, diucapkan di persidangan dan bertujuan untuk mengakhiri atau menyelesaikan suatu perkara atau sengketa antara para pihak..$^{19}$ Melalui definisi ini tampak bahwa putusan hakim itu bertujuan mengakhiri atau menyelesaikan suatu sengketa. Dalam PTUN, sengketa yang dimaksud adalah sengketa yang timbul dalam bidang tata usaha negara antara orang atau badan hukum perdata dengan Badan atau Pejabat Tata Usaha Negara, baik di pusat maupun di daerah, sebagai akibat dikeluarkannya KTUN, termasuk sengketa kepegawaian ' berdasarkan peraturan perundang-undangan yang berlaku. ${ }^{20}$ Berdasarkan rumusan ini tampak bahwa sumber lahirnya sengketa adalah keputusan tata usaha negara, oleh karena itu putusan hakim PTUN yang utama adalah membebankan kewajiban kepada tergugat untuk; (a) mencabut KTUN yang disengketakan; (b) mencabut KTUN yang disengketakan dan menerbitkan KTUN baru; (c) menerbitkan KTUN dalam. hal gugatan didasarkan pada Pasal 3 UU PTUN. Di samping itu, putusan hakim PTUN dimungkinkan pula memuat ganti rugi yang harus dipikul oleh tergugat dan mewajibkan tergugat untuk merehabilitir penggugat dengan atau tanpa konpensasi dalam hak sengketa kepegawaian. Berbeda dengan putusan dalam hukum acara.perdata yang hanya mengikat pihak-pihak yang berperkara, putusan PTUN memiliki sifat erga omnes yaitu mengikat pihak-pihak lain selain pihak yang bersengketa. Adanya sifat erga omnes in secara praktis menyebabkan Pasal 83 UU PTUN mengenai intervensi, voeging, vrijwaring, dan tussenkomst, menjadi tidak perlu, bahkan bertentangan. ${ }^{21}$

${ }^{19}$ Sudjkno Mertokusumo. 1981. Hukum Acara Perdata Indonesia:Yogyakarta: Liberty. HIm. 158. ${ }^{20}$ Pasal 1 angka (4) UU PTUN.

${ }^{21 S F}$. Marbun. 1997. Peradilan Administrasi dan Upaya Administratif di Indonesia. Yogyakarta' Liberty. HIm. 211, lihat pula Philipus M. Hadjon, et.al. Op. Cit. HIm. 314. 
Telah disebutkan bahwa putusan hakim PTUN itu membebankan kewajiban yang harus dipikul oleh tergugat. Sebagai suatu kewajiban, isi putusan itu harus dipenuhi atau dilaksanakan oleh tergugat dan pelaksanaan putusan PTUN hanya dapat dilakukan terhadap putusan yang telah memperoleh kekuatan hukum tetap (kracht van gewijsde), sebagaimana ditentukan dalam Pasal 115 UU PTUN; "hanya putusan Pengadilan yang telah memperoleh kekuatan hukum tetap yang dapat dilaksanakan". Ketentuan -pasal ini dengan sendirinya menolak pelaksanaan putusan yang belum memperoleh kekuataan hukum tetap (uivoorbaar bij vooraad).

Dalam pelaksanaan putusan PTUN terdapat dua jenis eksekusi yaitu: eksekusi otomatis dan eksekusi hirarkis. Eksekusi otomatis terdapat dalam Pasal 116 ayat (2) yaitu; "Dàlam hal empat bulan setelah putusan pengadilan yang telah memperoleh kekuatan hukum yang tetap sebagaimana dimaksud dalam ayat (1) dikirimkan tergugat tidak melaksanakan kewajibannya sebagaimana dimaksud dalam Pasal 97 ayat (9) huruf a, maka KTUN yang disengketakan itu tidak mempunyai kekuatan hukum", sedangkan eksekusi hirarkis terdapat dalam Pasal 116 ayat (4). (5), dan (6) yang berbunyi sebagai berikut:

(4) Jika tergugat masih tidak mau melaksanakannya, ketua pengadilan mengajukan hal ini kepada instansi atasannya menurut jenjang jabatan.

(5) Instansi atasan sebagaimana dimaksud dalam ayat (4), dalam waktu dua bulan setelah menerima pemberitahuan dari ketua pengadilan harus sudah memerintahkan pejabat sebagaimana dimaksud dalam ayat (3) melaksanakan putusan pengadilan tersebut.

(6) Dalam hal instansi atasan sebagaimana dimaksud dalam ayat (4), tidak mengindahkan ketentuan sebagaimana dimaksud dalam ayat (5), maka ketua pengadilan mengajukan hal ini kepada presiden sebagai pemegang kekuasaan pemerintah tertinggi untuk memerintahkan pejabat tersebut melaksanakan putusan pengadilan tersebut.

Persoalan yang sering muncul berkenaan dengan pelaksanaan putusan adalah banyaknya pejabat yang kalah berperkara, namun tidak mau melaksanakan putusan PTUN meskipun sudah diberi peringatan. Menurut Benjamin Mangkudilaga, ada sejumlah pejabat yang tidak mematuhi putusan pengadilan, perbandingannya sekitar 60 persen yang melaksanakan dan 40 persen membandel. Terhadap ketidakpatuhan pejabat ini muncul sejumlah usulan. Benjamin mengusulkan agar pejabat yang membandel dikenakan pidana atau diumumkan secara terbuka, sedang Abdul Hakim Garuda Nusantara mengusulkan agar pejabat yang membandel tersebut dikatagorikan melakukan contempt of court. Menurutnya contempt of court tidak hanya terbatas pada pelecehan di depan sidang, tetapi juga tindakan yang melecehkan pengadilan. ${ }^{22}$

22Farum Keadilan Nomor 22 Tahun:ll. 17 Pebruari 1994, Hlm. 24. 
Persoalan ketidakpatuhan terhadap putusan pengadilan yang telah memiliki kekuatan hukum tetap itu sebenarnya tidak semata-mata karena ketidakmauan dari pejabat yang bersangkutan, tetapi juga karena ada beberapa kendala yang terdapat dalam hukum administrasi; yang merupakan hukum materil. Philipus M. Hadjon menyebutkan beberapa'asas hukum administrasi yang dapat menjadi kendala dalam pelaksanaan eksekusi, yaitu; Pertama, asas bahwa terhadap benda-benda publik tidak dapat diletakkan sita jaminan; Kedua, asas 'rechtmatigheid van bestuur'. Salah satu konsekuensi asas ini adalah asas kewenangan. Pejabat atasan tidak dibenarkan menerbitkan KTUN yang seharusnya menjadi wewenang pejabat tertentu di bawahnya. Dengan demikian andaikata pejabat atasan memerintahkan pejabat di bawahnya untuk menerbitkan KTUN dan ternyata tidak dilakukan, pejabat atasan tidak bisa menerbitkan KTUN tersebut; Ketiga, asas bahwa kebebasan pejabat pemerintahan tidak bisa dirampas. Kemungkinan dari asas ini misalnya tidak mungkin seorang pejabat dikenai tahanan rumah karena tidak melaksanakan putusan PTUN; Keempat, asas bahwa negara (dalam hal ini) pemerintah selalu harus dianggap 'solvable' (mampu membayar). ${ }^{23}$

Di atas telah disebutkan bahwa yurisprudensi telah memperluas cakupan tergugat, bukan hanya Badan atau Pejabat Tata Usaha Negara tetapi juga badan hukum. perdata yang diberi wewenang melaksanakan sebagian urusan pemerintahan. Berkenaan dengan eksekusi hirarkis, akan muncul persoalan tentang siapa atasan dari badan hukum swasta? Artinya siapa yang akan memerintahkan badan swasta yang kalah berperkara dan tidak mematuhi putusan pengadilan? Dengan kata lain, instrumen hukum apa yang dapat dikenakan terhadap badan hukum perdata yang tidak mematuhi putusan pengadilan? Dalam. UU PTUN dan berbagai peraturan terkait tidak terdapat jawabannya.

Terlepas dari kendala-kendala teoritis dan praktis dalam pelaksanaan putusan pengadilan tersebut, satu hal yang perlu diperhatikan adalah harus memuat ketentuan sanksi yang tegas dalam undang-undang PTUN. Salah satu kekurangan mendasar dalam pelaksanaan putusan adalah karena UU PTUN tidak memuat tentang pemberian sanksi bagi tergugat yang kalah berperkara. Memuat ketentuan sanksi merupakan hal penting dalam peraturan perundangundangan, karena normativisasi hukum tidak cukup hanya sekadar memuat perintah dan larangan: Dibalik larangan harus ada ketentuan sanksi atas ketidakpatuhan. Sanksi hukum sampai saat ini masih merupakan alat yang paling ampuh untuk menjaga wibawa hukum atau dengan kata lain agar setiap orang patuh terhadap hukum. ${ }^{24}$ Menuntut pelaksanaan kewajiban hukum dengan hanya berpegang pada kesadaran hukum (rechtsbewustheid) belaka tidak selalu membuahkan hasil yang memuaskan.

23Philipus M. Hadjon, et.al. Op. Cit. Hlm. 369

${ }^{24}$ Zairin Harahap. 1997. Hukum Acara Peradilan Tata Usaha Negara. Jakarta: Rajawali. Hlm. 147 


\section{Simpulan}

Salah satu kelemahan undang-undang sebagai hukum tertulis. adalah tidak dapat nenampung semua persoalan dan tidak dinamis dalam mengikuti perkembangan nasyarakat, undang-undang hanya sekadar merekam faktor-faktor yang paling berpengaruh pada' saat pembentukannyá, Jemikian pula halnya dengan UU PTUN. Oleh karena itu, pembaharuan undang-undang senantiasa diperlukan, sebagai upaya untuk meminimalisir kekurangan tersebut dan yang debih penting lagi sebagai langkah penyempurnaan menuju proses peradilan yang lebih menjamin kebenaran dan keadilan. Pembaharuan yang diperlukan di antaranya mengenai pengertian tergugat, tidak hanya Badan atau Pejabat Tata Usaha Negara, tetapi juga badan hukum lain yang diberi wewenang untuk menjalankan fungsi pemerintahan, pencantuman secara tegas asas-asas umum pemerintahan yang layak sebagai dasar pengujian KTUN, dan pemuatan ketentuan sanksi bagi pihak yang tidak mematuhi putusan pengadilan.

\section{Daftar Pustaka}

Belinfante, A.D. 1985. Kort Begrip van het Administratief Recht. Alphen aan den Rijn: Samsom Uitgeverij.

Berge, J.B.J.M. ten. 1996. Besturen door de Overheid. Deventer: W.E.J. Tjeenk Willink.

Derksen, W. en A.F.A. Korsten (redactie). 1989. Lokaal Bestuur in Nederland. Alphen aan den Rijn: Samsom H.D. Tjeenk Willink.
Haan, P. de, et.al. 1986. Bestuursrecht in de Sociale Rechtstaat. Deel 2. Deventer: Kluwer.

Hadjon, Philipus M., et.al. 1993. Pengantar Hukum Administrasi Indonesia. Yogyakarta: Gadjah Mada University Press.

"Pemerintahan Menurut Hukum (Weten Rechtmatig Bestuur)." Makalah tidak dipublikasikan.

Harahap, Zairin. 1997. Hukum Acara Peradilan Tata Usaha Negara. Jakarta: Rajawali.

Huisman, R.J.H.M.. . Tt. Algemeen Bestuursrecht, een Inleiding. Amsterdam: Kobra.

Indroharto. 1994. Usaha Memahami Undang-undang tentang Peradilan Tata Usaha Negara. Buku I. Jakarta: Pustaka Sinar Harapan.

Lotulung, Paulus E. "Problematika PTUN." Makalah pada Penataran Hukum Administrasi Negara. Diselenggarakan di Fakultas Hukum Universitas Airlangga. Surabaya, 13 Januari 1995.

Marbun, SF. 1997. Peradilan Administrasi dan Upaya Administratif di Indonesia. Yogyakarta: Liberty.

Mertokusumo, Sudikno. 1981. Hukum Acara Perdata Indonesia. Yogyakarta: Liberty.

Romeijn, H.J. 1934. Administratiefrecht Hand-en Leerboek. Den Haag: Moorman's Periodieke Pers N.V. Hlm.

Versteden, C.J.N. 1984. Inleiding Algemeen Bestuursrecht. Alphen aan den Rijn: Samsom H.D. Tjeenk Willink. 
Farum Keadilan Nomor 22 Tahun II. 17 Pebruari 1994, HIm. 24

Forum Keadilan No. 28. Maret 1991. HIm. 25

Varia Peradilan No. 186 Tahun 2001. Hlm. 132-134

Ketetapan MPR No. III/MPR/2000 tentang Sumber Hukum dan Tata Urutan Peraturan Perundang-undangan
Undang-undang Nomor 14 Tahun 1970 jo. UU No. 35 Tahun 1999 tentang Ketentuanketentuan Pokok. Kekuasaan Kehakiman

Undang-undang Nomor 14 Tahun 1985 tentang Mahkamah Agung.

Undang-undang Nomor 5 Tahun 1986 tentang Peradilan Tata Usaha Negara.

๑๑ 